\title{
EFFECT OF DIETARY FISH OIL ON MAMMARY GLAND DEVELOPMENT AND MILK PRODUCTION OF HOLSTEIN COW*
}

\author{
Hoda Javaheri Barfourooshi1,2, Armin Towhidi ${ }^{1 *}$, Hassan Sadeghipanah², Mahdi Zhandi ${ }^{1}$, \\ Saeed Zeinoaldini ${ }^{1}$, Essa Dirandeh ${ }^{3}$, Robert M. Akers ${ }^{4}$ \\ ${ }^{1}$ Department of Animal Science, College of Agriculture and Natural Resources, University of Tehran, \\ Karaj, Iran \\ ${ }^{2}$ Animal Science Research Institute of Iran, Agricultural Research, \\ Education and Extension Organization (AREEO), Karaj, Iran \\ ${ }^{3}$ Department of Animal Science, Sari Agricultural Sciences and Natural Resources University, \\ Sari, Iran \\ ${ }^{4}$ Department of Dairy Science, Virginia Tech, Blacksburg VA 24061, USA \\ •Corresponding author: atowhidi@ut.ac.ir
}

\begin{abstract}
The aim of this study was to evaluate the effect of feeding oil supplement on mammary gland development and milk production responses in Holstein cows. Ten multiparous Holstein cows (42.2 $\pm 9.2 \mathrm{~d}$ before calving, $3.25 \pm 0.25$ body condition score, and $620 \pm 35 \mathrm{~kg}$ body weight) were randomly assigned to treatments. Treatments were a diet with oil added as palm oil (PO; $\mathrm{n}=5$ ), or fish oil (FO; $\mathrm{n}=5$ ) given to cows until $63 \mathrm{~d}$ in milk. Milk yield was recorded daily, milk composition (fat, protein, lactose, total solid and somatic cell count) was measured weekly and fatty acid profiles of milk fat were determined at first and last week of the experiment. Samples of mammary tissue were obtained at 7 and $63 \mathrm{~d}$ in milk by biopsy gun. Tissue slides were analyzed by Image $J$ software. Results showed that fish oil supplemented diet compared to the palm oil supplemented diet increased milk production after 6 weeks of lactation $(P<0.05)$, content of polyunsaturated fatty acids milk fat $(\mathrm{P}<0.05)$ and docosahexaenoic acid $(\mathrm{P}<0.01)$. Moreover, $n-6: n-3$ ratio was decreased by fish oil supplement $(\mathrm{P}<\mathbf{0 . 0 5})$. Histological studies showed that $\mathrm{FO}$ increased the relative percentage of tissue area occupied by epithelial cells as well as a number of total alveoli in each microscopic field $(\mathrm{P}<\mathbf{0 . 0 5})$. Data suggested that feeding fish oil during the dry period and early lactation could improve development and function of the mammary gland in the dairy cow.
\end{abstract}

Key words: dairy cows, fat supplementation, mammary development, milk yield, milk fat, fatty acid profile

The dry period is a critical part of the lactation cycle because of the dramatic regression and redevelopment of the mammary gland (Akers, 2002; Wall et al., 2005; De Vries et al., 2010). In recent years, dietary fats rich in $n-3$ polyunsaturated fatty acid ( $n$-3 PUFA) have been widely used to enhance physiological well-being and

\footnotetext{
* Work financed from: University of Tehran, under the grant number 7108017/6/18.
} 
reproductive performance (Piantoni et al., 2013; Dirandeh et al., 2015, 2016). Examples include increased dietary energy density (Ferguson et al., 1990), decreased insulin resistance (Kasaghaei et al., 2015; Dirandeh et al., 2016) and alterations in follicular growth and ovulation (Dirandeh et al., 2013 b). Such diets can increase plasma progesterone (Jahani-Moghadam et al., 2015) and decrease uterine $\mathrm{PGF}_{2} \alpha$ secretion to impact reproduction (Dirandeh et al., 2015). A number of cancer studies (Welsch, 1992; McLennan and Ma, 2010; Liu and Ma, 2014) have indicated that manipulation of dietary fats can markedly impact mammary growth and development. It is also well recognized that fats and fatty acids are useful for increasing energy content and palatability of dairy cow diets (Coppock and Wilks, 1991). Many of these fats also contain bioactive fatty acids, such as $n-3$ and $n-6$ fatty acids. These long chain polyunsaturated fatty acids (LC-PUFAs) participate in biological processes (Dirandeh et al., 2016; Calder, 2009 b) that are likely to impact mammary development and function (Lin and Li, 2005; Mach et al., 2011).

However, studies on the effects of such fats on mammary development and function in ruminants are limited and typically have focused on mammary development in heifers or milk secretion in mid-lactation rather than during the dry and early lactation periods (Hovey et al., 1999; Sejrsen et al., 2000; Mach et al., 2011).

Our objective was to evaluate the effect of oil added as palm oil or fish oil to the diet during the dry period and early lactation on the development of the mammary gland and production performance and milk composition of dairy cows.

\section{Material and methods}

All experimental procedures were performed in accordance with the Guide for the Care and Use of Agricultural Animals in Research and Teaching (FASS, 2010). This study was performed according to the procedures laid down by the Iranian Ministry of Agriculture (experimental permission no. 858).

\section{Experimental design, animals and treatments}

This study was carried out on the research farm of the University of Tehran (Iran) using dairy cows. Ten multiparous (average in third lactation) Holstein cows ( $3.25 \pm 0.25$ body condition score, $620 \pm 35 \mathrm{~kg}$ body weight) from 45 days before their expected calving until the day 63 of lactation were used in completely randomized design. The cows were drying off $8 \mathrm{wk}$ before expected calving and on the day -42 (42.2 $\pm 9.2 \mathrm{~d}$ ) were entered into the experiment. The assignment of cows to the experimental groups was carried out according to their lactation number and milk production record in the last lactation. Cows were placed in the individual box stall and fed a diet supplemented with fish oil (FO) or palm oil (PO) to a basal diet. Supplemental oils were added to a basal diet. The FO diet was created by using the addition of Optomega 50 (Optomega 50, Optivite International Ltd., UK). The fatty acids (FA) profile of palm oil (Prilled palm oil, Ecolex Sdn. Bhd., Malaysia), according to the company report and expressed as a percentage of total FA, included 76\% 16:0, 4\% 18:0, 16\% 18:1, and 4\% 18:2; and for Optomega $5022 \%$ SFA, 45\% MUFA, and 33\% 
PUFA (4\% cis-6 18:2, 2\% cis-3 18:3, 2\% 18:4, 2\% 20:4, 8\% 20:5, 3\% 22:5, and $12 \%$ 22:6), respectively.

Table 1. Ingredient and chemical composition of diets based on the palm oil $(\mathrm{PO}, \mathrm{n}=5)$ or the fish oil $(\mathrm{FO}, \mathrm{n}=5)$ at different stages of lactation period

\begin{tabular}{|c|c|c|c|c|c|c|c|}
\hline & \multicolumn{7}{|c|}{ Type of diet ${ }^{1}$} \\
\hline & \multirow{2}{*}{ Far off } & \multicolumn{2}{|c|}{ Close up } & \multicolumn{2}{|c|}{ Fresh } & \multicolumn{2}{|c|}{ Early lactation } \\
\hline & & $\mathrm{PO}^{*}$ & FO & $\mathrm{PO}$ & FO & PO & FO \\
\hline \multicolumn{8}{|c|}{ Ingredient composition (\% of dry matter) } \\
\hline Alfalfa hay & 22.7 & 32.1 & 32.1 & 28.6 & 28.6 & 19.5 & 19.5 \\
\hline Grass hay & 36.7 & - & - & - & - & - & - \\
\hline Corn silage $10 \%$ grain & - & 28.2 & 28.2 & 15.9 & 15.9 & 24.0 & 24.0 \\
\hline Wheat straw & 13.4 & - & - & - & - & - & - \\
\hline Beet pulp & - & - & - & 6.57 & 6.57 & 4.33 & 4.33 \\
\hline Barley grain & 3.93 & 11.9 & 11.9 & 14.0 & 14.0 & 14.6 & 14.6 \\
\hline Corn grain & - & 5.95 & 4.27 & 8.00 & 7.75 & 5.22 & 4.96 \\
\hline Soybean meal & 8.68 & 7.52 & 7.52 & 13.5 & 13.5 & 9.39 & 9.39 \\
\hline Corn gluten meal & - & - & - & 1.50 & 1.50 & 1.04 & 1.04 \\
\hline Meat meal & - & - & - & 0.50 & 0.50 & 1.04 & 1.04 \\
\hline Cottonseed, whole & - & - & - & 3.75 & 3.50 & 2.61 & 2.61 \\
\hline Wheat grain & 2.22 & 3.96 & 4.36 & 2.50 & 2.50 & 5.22 & 5.22 \\
\hline Sunflower meal & - & - & - & - & - & 6.78 & 6.78 \\
\hline Optomega 50 & $* *$ & - & 0.80 & - & 2.00 & - & 2.08 \\
\hline Palm oil hydro & $* *$ & 0.40 & - & 1.00 & - & 1.04 & - \\
\hline Wheat bran & 10.7 & 5.94 & 6.14 & - & - & 0.89 & 0.63 \\
\hline $\begin{array}{l}\text { Vitamin and mineral } \\
\text { supplement }\end{array}$ & 0.5 & 0.47 & 0.47 & 0.50 & 0.50 & 0.73 & 0.73 \\
\hline Sodium bicarbonate & - & - & - & 0.75 & 0.75 & 0.83 & 0.83 \\
\hline Salt & 0.15 & 0.08 & 0.08 & 0.15 & 0.15 & 0.21 & 0.21 \\
\hline Limestone & 0.30 & 0.55 & 0.55 & 0.10 & 0.10 & 0.41 & 0.41 \\
\hline Dicalcium phosphate & - & 0.16 & 0.16 & 0.55 & 0.55 & 0.31 & 0.31 \\
\hline Anionic salt & - & 1.52 & 1.52 & - & - & - & - \\
\hline Zeolite & 0.59 & - & - & 0.90 & 0.40 & 1.56 & 1.04 \\
\hline Biotin vit. & - & - & - & 0.07 & 0.07 & 0.08 & 0.08 \\
\hline Glycoline & - & 1.19 & 1.19 & 1.00 & 1.00 & - & - \\
\hline Micozorb & 0.06 & 0.08 & 0.08 & 0.07 & 0.07 & 0.05 & 0.05 \\
\hline Magnesium oxide & - & - & - & 0.15 & 0.15 & 0.17 & 0.17 \\
\hline \multicolumn{8}{|c|}{ Chemical composition ${ }^{2}$} \\
\hline NEL (Mcal/kg of dry matter) & 1.37 & 1.50 & 1.50 & 1.64 & 1.64 & 1.60 & 1.60 \\
\hline NDF ( $\%$ of dry matter) & 53.9 & 37.0 & 37.2 & 32.2 & 32.0 & 31.8 & 32.0 \\
\hline NFC ( $\%$ of dry matter) & 25.2 & 37.3 & 37.0 & 37.2 & 37.0 & 36.9 & 37.0 \\
\hline $\mathrm{CP}(\%$ of dry matter $)$ & 14.3 & 15.0 & 15.0 & 17.4 & 17.3 & 17.1 & 17.2 \\
\hline Fat ( $\%$ of dry matter) & 2.2 & 3.10 & 3.10 & 4.10 & 4.10 & 3.98 & 4.01 \\
\hline $\mathrm{Ca}(\%$ of dry matter $)$ & 0.80 & 0.84 & 0.87 & 0.83 & 0.82 & 0.91 & 0.92 \\
\hline $\mathrm{P}(\%$ of dry matter $)$ & 0.30 & 0.43 & 0.44 & 0.44 & 0.44 & 0.49 & 0.50 \\
\hline
\end{tabular}

${ }^{1}$ Far off (from day -42 up to -15 of parturition), Close up (from -15 up to parturition), Fresh (from parturition up to day 21 of lactation), Early lactation (from day 21 up to day 63 of lactation). ${ }^{*}$ PO: diet containing palm oil; FO: diet containing fish oil. $* * 150 \mathrm{~g} / \mathrm{cow} /$ day as top dressing. ${ }^{2} \mathrm{NE}_{\mathrm{L}}=$ Net energy of lactation, $\mathrm{NDF}=\mathrm{Neutral}$ detergent fiber, $\mathrm{NFC}=$ Non-fiber carbohydrate, $\mathrm{CP}=$ Crude protein. 
Diets were formulated according to NRC (2001) nutrient requirements for dairy cows during the dry period and early lactation which included four rations; far off (from day -42 up to -15 ), close up (from day -15 up to parturition), fresh (from parturition up to day 21 of lactation) and early lactation (from day 21 up to day 63 of lactation) diets. In the far off period fat supplements $(150 \mathrm{~g} / \mathrm{cow} /$ day $)$ were added to the diet as a top dressing (Table 1).

Total mixed rations were sampled every $2 \mathrm{wk}$ and pooled on a 4 -wk basis. Feed samples were dried at $65^{\circ} \mathrm{C}$ for $24 \mathrm{~h}$ and then ground to pass through a $1-\mathrm{mm}$ screen (Cutting Mill SM 100, Retsch GmbH, Haan, Germany). Samples were analyzed for DM, CP, NDF, and ADF according to the methods of the AOAC International (2000).

\section{Body weight and body condition score}

Body weight and body condition score (BCS) [based on 1 (thin) to 5 (obese) scale; Edmonson et al., 1989] were determined on day -42, 0, 7, 14, 21, 28, 35, 42, 49, 56 and 63 . The scores were given by one experienced veterinarian.

\section{Milk production and milk composition}

Cows were milked 3 times daily at 0615,1430 , and $2300 \mathrm{~h}$ using milking units equipped with electronic milk meters (Westfalia, Dematron 70, Germany). Milk production was recorded at every milking. Milk samples were taken weekly from each of three daily milking then pooled in proportion to the daily yield to provide a sample for analysis of fat, protein, and lactose by infrared spectroscopy (MilkoScan ${ }^{\mathrm{TM}}$ FT6000, Foss Alle, Denmark, method 972.16). Somatic cell counts (SCC) were determined by DNA staining and its microscopic counting.

\section{Milk fatty acid profiles}

Milk was sampled from 3 consecutive milkings on 4 and $63 \mathrm{~d}$ in milk. The milk fat was separated using the two steps procedure outlined by Feng et al. (2004). The isolated lipid fraction was used for methylation as described by Ichihara and Fukubayashi (2010). The methylated fatty acids were subsequently separated and quantitated using an Agilent 6890 N Network Gas Chromatograph (Agilent Technologies Inc., USA) equipped with a flame-ionization detector, split injection port and a $30 \mathrm{~m}$ column (DB-FFAP, Agilent, USA) with a $0.32 \mathrm{~mm}$ inside diameter. Nitrogen was used as the carrier gas with flow rate $2 \mathrm{ml} / \mathrm{min}$. The injector and detector temperatures were $240^{\circ} \mathrm{C}$ and $260^{\circ} \mathrm{C}$, respectively, and the split ratio was 30 . The oven temperature was set at $120^{\circ} \mathrm{C}$ for $7 \mathrm{~min}$. The temperature was then increased $2^{\circ} \mathrm{C} / \mathrm{min}$ to $230^{\circ} \mathrm{C}$ and held for $15 \mathrm{~min}$.

\section{Mammary gland biopsy samples}

Two biopsy samples were obtained from the mammary gland of each cow on days 7 and 63 of lactation. Biopsies were taken according to the procedure described by Safayi et al. (2010) as modified for cattle. Briefly, mammary biopsies were collected from the right rear quarters immediately after morning milking to minimize milk remaining in the udder. After washing with surgical iodine scrub, the caudal surface 
of mammary rear quarters was shaved and disinfected with iodine and $70 \%$ ethanol, the biopsy site was anesthetized by injecting about $4 \mathrm{ml}$ of lidocaine hydrochloride (20 $\mathrm{mg} / \mathrm{ml})$ subcutaneously in multiple sites surrounding the biopsy site. Biopsies were obtained by using a semi-automatic $14 \mathrm{G}$ biopsy gun (TSK Laboratory, TochigiKen, Japan). Each sample contained approximately 15 to $20 \mathrm{mg}$ of tissue. A maximum of three samples was collected at each time. Tissue samples were placed in $4 \%$ buffered paraformaldehyde solutions for fixation. After the biopsy, the mammary quarter was milked by hand to check for blood in milk and to remove any blood clots from mammary ducts and then cows were milked by machine thrice daily. After 3 to 4 milkings (about 1.5 days after sampling), there was no visible evidence of blood in milk. Cows received the following postoperative treatments: tetracycline spray on biopsy area, intramuscular injections of vitamin $\mathrm{K}$, dexamethasone and penicillin for reducing pain and prevention of infection. Antibiotic therapy continued for three days. No mastitis signs were observed and cows quickly recovered.

\section{Staining of mammary tissue samples}

Fixed mammary tissue samples were processed as described by Norgaard et al. (2008). Paraffin embedded tissue samples were sectioned at $4 \mu \mathrm{m}$. Two to three serial tissue sections were taken at $30 \mu \mathrm{m}$ intervals into the tissue and mounted on each of two microscope slides. Slides were deparaffinized and stained with HaematoxylinEosin (H\&E). All slides were studied by light microscopy (OLYMPUS BX40 F4, Olympus, Optical Co., Tokyo, Japan) by the same person, and each sample was assigned a code to mask its identity at the time of analysis to ensure unbiased results. From each stained section, six random images were captured at $20 \times$ magnifications on a light microscope with a top-mounted digital microscope camera (SDC-313B, Samsung Engineering Co., Ltd., Seoul, Korea) connected to a computer, as described by Brown et al. (2005). Each image was centred in an area predominantly occupied by epithelial cells. Areas high in the interlobular stroma or areas close to tissue section edges were avoided. Twenty-four images were taken from each biopsy sample.

\section{Photographic analysis and area measurements}

The images were studied by using a digital image analysis program, Image $\mathrm{J}$ software (Abramoff et al., 2004). Each section covered a tissue area of 58,834 $\mu \mathrm{m}^{2}$. A digital 88-point transparent grid was placed on each image and the number of times intersections were transposed over epithelial cells per slide, luminal space or intralobular stroma were counted and tabulated for all images (Chalkey, 1943). The number of these parameters was transformed to the percentage. In addition, direct measurements of the area occupied by alveolar epithelium and by luminal space were obtained using the "freehand" selection tool available in the Image J software. Specifically, the area $\left(\mu \mathrm{m}^{2}\right)$ occupied by luminal space, epithelial cells or the total alveolar area (epithelium + lumen) were measured and tabulated for each image. Values for each animal at each biopsy period were averaged and submitted for statistical analysis. The "multi point" selection tools feature was used to count the number of epithelial cells in each identified alveolar profile (epithelial cell per alveolus) as 
well as the total number of alveoli within each image. We classified the alveoli and lumens based on their diameters into five size classes; from $<50 \mu \mathrm{m}$ to $>110 \mu \mathrm{m}$ for alveoli, and from $<20 \mu \mathrm{m}$ to $>80 \mu \mathrm{m}$ for lumen diameters. The number of alveoli and lumens in each size class were counted and tabulated for subsequent statistical analysis.

\section{Statistical analysis}

Data for milk production, milk composition, milk fatty acid profile and tissue were analyzed using repeated measures responses of the mixed model procedure of SAS 9.1 (SAS Institute, 2000), with the following model:

$$
Y_{i j k}=\mu+T_{i}+A_{(i) j}+S_{k}+(T \times S)_{j k}+\varepsilon_{i j k}
$$

where:

$\mu$ is the population mean,

$T_{i}$ is a population parameter corresponding to treatment (diet) $i$,

$A_{(i) j}$ is the random effect of cow in the treatment (diet),

$S_{k}$ is the fixed effect of sampling day or time $k$,

$(T \times S)_{j k}$ is the interaction effects of treatment and sampling day or time,

$\varepsilon_{i j k} i s$ the residual error.

The statistical model included the fixed effects of diet, time and their interaction and the random effects of cow within the diet, assuming an autoregressive order. Data were reported as least square mean (LSMeans) \pm SEM. Body weight was included as a covariate. Comparison of LSMEANS was conducted by including PDIFF option in the LSMEANS statement. Significance was declared at $\mathrm{P}<0.05$.

\section{Results}

Dry matter intake (DMI), BCS, milk production, milk composition and somatic cell count (SCC)

Fish oil supplementation did not affect DMI and BCS. Overall milk yield did not differ between groups. There was an interaction between treatment $\times$ week so that milk yield increased from week 6 to 8 postpartum in FO compared to $\mathrm{PO}(\mathrm{P}<0.05$, Figure 1).

Milk composition was similar between two groups, except milk fat percentage and yield, which was less in FO compared to PO (P<0.05, Table 2). SCC had tended to be lower and somatic cell score (SCS) was lower in $\mathrm{FO}(\mathrm{P}=0.01)$ compared to PO. 


\section{Effect of dietary treatments on fatty acid profile of milk fat}

The fatty acid composition of milk was affected by diets (Table 3). Percentage of the fatty acid smaller than 16 carbon decreased in FO compared to $\mathrm{PO}(\mathrm{P}<0.05)$. There was an interaction between treatment $\times$ week for the changes in the percentage of C13:0, so that its amount was significantly decreased for FO over the time. Also, fish oil consumption significantly reduced the percentage of omega- 6 fatty acids and increased the percentage of omega- 3 fatty acids in milk fat. The long chain fatty acid (bigger than 20C) percentage was increased in FO compared to $\mathrm{PO}$ and there had been an increase over the time for both groups $(\mathrm{P}<0.05)$. Consumption of fish oil caused a decrease in the percentage of saturated fatty acids, and an increase in the percentage of $n-3$ polyunsaturated fatty acids of milk fat, especially for docosahexaenoic acid (DHA). Feeding fish oil decreased the percentage of monounsaturated fatty acids over the time for FO and decreased the monounsaturated fatty acids to the polyunsaturated fatty acids and the $n-6$ to $n-3$ ratios in the FO compared to $\mathrm{PO}(\mathrm{P}<0.05)$. The health index calculated for milk fat was greater in FO than $\mathrm{PO}(\mathrm{P}<0.05)$. The health index contains a summation of some unsaturated fatty acids such as $16: 1,18: 1,18: 2$ and 18:3n-3 to summation of three saturated medium chain fatty acids (12:0, 14:0 and 16:0). These saturated medium chain fatty acids are known to increase the risk of cardiovascular disease.

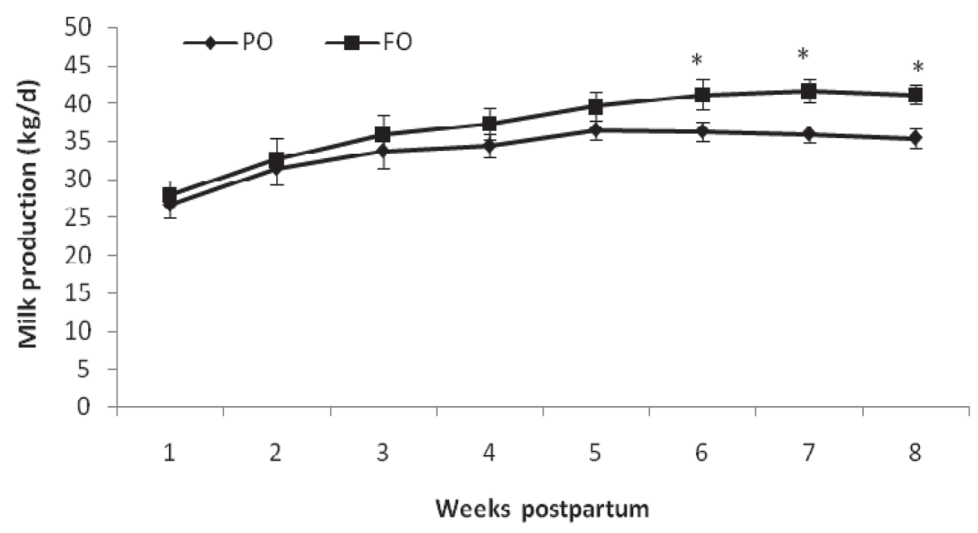

*Referred to significance at $\mathrm{P}<0.05$ level.

Figure 1. LS Means of milk production in Holstein cows fed diets supplemented with palm oil $(\mathrm{PO}, \mathrm{n}=5)$ or fish oil $(\mathrm{FO}, \mathrm{n}=5)$ from day -42 to day 63 of lactation 
Table 2. Average body weight (BW), body condition score (BCS), dry matter intake (DMI), milk production and milk composition (LS Means) in Holstein cows fed diets supplemented with palm oil

$(\mathrm{PO}, \mathrm{n}=5)$ or fish oil $(\mathrm{FO}, \mathrm{n}=5)$ from day -42 to day 63 of lactation

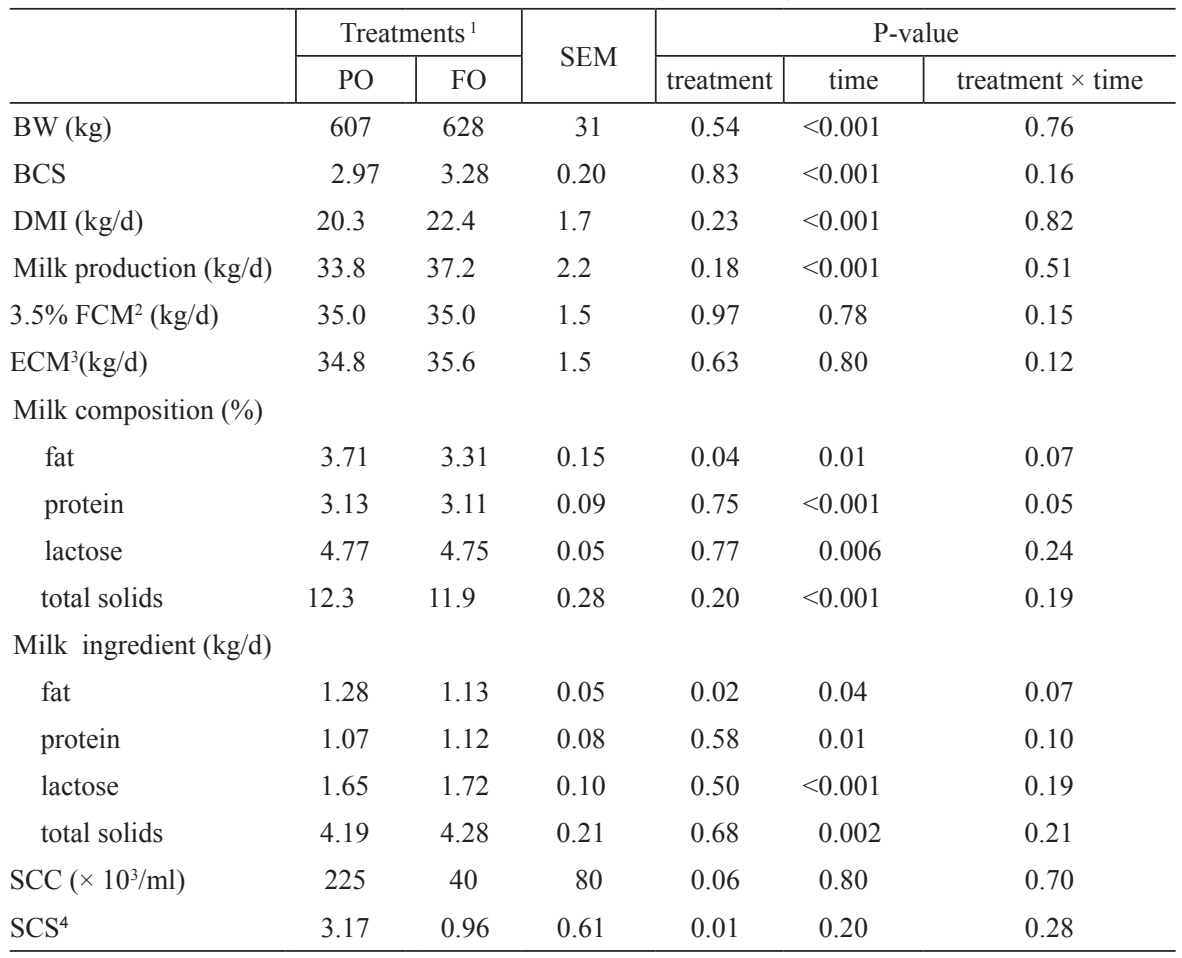

${ }^{1} \mathrm{PO}$ : Palm oil diet; FO: Fish oil diet.

${ }^{2} \mathrm{FCM}=$ Fat corrected milk.

${ }^{3} \mathrm{ECM}=$ Energy corrected milk.

${ }^{4}$ Somatic Cell Score, calculated as ((LOG10× (SCC/1000)-20)/LOG10 (2)) +3, based on Ordway et al. (2002).

\section{Effect of dietary treatments on mammary tissue characteristics}

Feeding fish oil significantly affected histological parameters (Table 4). Although there was an interaction between treatment $\times$ week for the amount of stroma and lumen, where the amount of stroma decreased and lumen increased in the mammary gland tissue, but these changes for $\mathrm{PO}$ were greater than $\mathrm{FO}(\mathrm{P}<0.05)$. These trends were also visible in the alveoli area, lumen area and the number of epithelial cells per alveolus. The relative area occupied by overall epithelial cells (per slide) was significantly higher in FO compared to $\mathrm{PO}$ on both biopsy days $(\mathrm{P}<0.05)$. On day 7 postpartum, the proportion of area occupied by stromal tissue was lower in FO than $\mathrm{PO}(\mathrm{P}<0.05)$. On day 63, the area occupied by luminal space was greater in $\mathrm{PO}$ compared to FO $(\mathrm{P}<0.05$; Figure 2-A). Direct measurement of an alveolar area (epithelium + luminal space) was also greater on day 63 vs. day 7 for both groups (Figure 2-B). The average number of alveoli and epithelial cells per alveolus did not differ between experimental groups (Figure 2-C). 
Table 3. Average fatty acid composition of milk on 4 and $63 \mathrm{~d}$ in milk in Holstein cows fed diets supplemented with palm oil $(\mathrm{PO}, \mathrm{n}=5)$ or fish oil $(\mathrm{FO}, \mathrm{n}=5)$ from day -42 to day 63 of lactation (LSMeans)

\begin{tabular}{|c|c|c|c|c|c|c|}
\hline & \multicolumn{2}{|c|}{ Treatments $^{1}$} & \multirow{2}{*}{ SEM } & \multicolumn{3}{|c|}{ P-value } \\
\hline & $\mathrm{PO}$ & $\mathrm{FO}$ & & treatment & time & treatment $\times$ time \\
\hline \multicolumn{7}{|c|}{ Fatty acid $(\mathrm{g} / 100 \mathrm{~g}$ of milk fat $)$} \\
\hline $\mathrm{C} 8: 0$ & 0.71 & 0.62 & 0.08 & 0.28 & 0.009 & 0.93 \\
\hline $\mathrm{C} 10: 0$ & 1.73 & 1.22 & 0.13 & 0.006 & 0.02 & 0.94 \\
\hline $\mathrm{C} 11: 0$ & 0.08 & 0.06 & 0.01 & 0.07 & 0.03 & 0.67 \\
\hline $\mathrm{C} 12: 0$ & 2.00 & 1.59 & 0.16 & 0.04 & 0.005 & 0.89 \\
\hline $\mathrm{C} 13: 0$ & 0.12 & 0.08 & 0.02 & 0.16 & 0.02 & 0.01 \\
\hline $\mathrm{C} 14: 0$ & 7.07 & 5.08 & 0.42 & 0.002 & 0.03 & 0.26 \\
\hline $\mathrm{C} 14: 1$ & 0.48 & 0.39 & 0.10 & 0.35 & 0.01 & 0.31 \\
\hline $\mathrm{C} 15: 0$ & 0.75 & 0.61 & 0.09 & 0.18 & 0.005 & 0.85 \\
\hline C15:1 & 0.21 & 0.14 & 0.03 & 0.05 & 0.85 & 0.76 \\
\hline C16:0 & 26.1 & 22.6 & 1.6 & 0.07 & 0.17 & 0.86 \\
\hline C16:1 & 1.51 & 1.61 & 0.13 & 0.46 & 0.02 & 0.20 \\
\hline C17:0 & 0.64 & 0.55 & 0.05 & 0.09 & 0.009 & 0.93 \\
\hline $\mathrm{C} 17: 1$ & 0.31 & 0.26 & 0.03 & 0.17 & 0.01 & 0.63 \\
\hline C18:0 & 9.55 & 7.98 & 0.66 & 0.05 & 0.003 & 0.63 \\
\hline C18:1 & 17.7 & 17.6 & 0.62 & 0.92 & 0.14 & 0.27 \\
\hline $\mathrm{C} 18: 2 n-6$ & 2.21 & 2.03 & 0.15 & 0.27 & 0.19 & 0.21 \\
\hline C18:3 n-6 & 0.08 & 0.05 & 0.01 & 0.01 & 0.71 & 0.17 \\
\hline $\mathrm{C} 18: 3 n-3$ & 0.30 & 0.35 & 0.01 & $<0.001$ & 0.03 & 0.61 \\
\hline $\mathrm{C} 18: 4 n-3$ & 0.15 & 0.31 & 0.03 & 0.002 & 0.43 & 0.12 \\
\hline C20:0 & 0.12 & 0.15 & 0.02 & 0.12 & 0.001 & 0.06 \\
\hline C20:1 & 0.20 & 0.19 & 0.03 & 0.86 & 0.02 & 0.54 \\
\hline $\mathrm{C} 20: 2 n-6$ & 0.71 & 0.61 & 0.07 & 0.21 & 0.005 & 0.59 \\
\hline $\mathrm{C} 20: 3 n-3$ & 0.14 & 0.15 & 0.02 & 0.87 & 0.06 & 0.71 \\
\hline $\mathrm{C} 20: 4 n-6$ & 0.17 & 0.14 & 0.02 & 0.18 & 0.14 & 0.54 \\
\hline $\mathrm{C} 20: 5 n-3$ & 0.05 & 0.19 & 0.02 & $<0.001$ & 0.02 & 0.13 \\
\hline $\mathrm{C} 21: 0$ & 0.09 & 0.03 & 0.01 & 0.004 & $<0.001$ & 0.20 \\
\hline $\mathrm{C} 22: 0$ & 0.11 & 0.18 & 0.04 & 0.10 & 0.08 & 0.08 \\
\hline $\mathrm{C} 22: 1$ & 0.40 & 0.56 & 0.02 & $<0.001$ & $<0.001$ & 0.04 \\
\hline $\mathrm{C} 22: 6 n-3$ & 0.02 & 0.55 & 0.01 & $<0.001$ & $<0.001$ & $<0.001$ \\
\hline C23:0 & 3.45 & 2.27 & 0.55 & 0.07 & 0.26 & 0.008 \\
\hline $\mathrm{C} 24: 0$ & 0.41 & 0.41 & 0.08 & 0.95 & 0.34 & 0.05 \\
\hline C24:1 & 8.43 & 7.75 & 0.46 & 0.19 & 0.02 & 0.03 \\
\hline Others & 14.1 & 23.7 & 1.96 & 0.002 & 0.97 & 0.83 \\
\hline SFA & 52.9 & 43.4 & 2.14 & 0.003 & 0.45 & 0.58 \\
\hline MUFA & 29.2 & 28.5 & 0.94 & 0.48 & 0.01 & 0.006 \\
\hline PUFA & 3.8 & 4.4 & 0.20 & 0.03 & 0.24 & 0.36 \\
\hline MUFA/PUFA ratio & 7.7 & 6.5 & 0.42 & 0.03 & 0.80 & 0.04 \\
\hline$n-6: n-3$ ratio & 4.78 & 1.84 & 0.32 & $<0.001$ & 0.58 & 0.25 \\
\hline Health Index ${ }^{2}$ & 0.39 & 0.50 & 0.03 & 0.008 & 0.07 & 0.86 \\
\hline
\end{tabular}

${ }^{1} \mathrm{PO}$ : Palm oil group; FO: Fish oil group.

${ }^{2}$ Calculated as $(16: 1+18: 1+18: 2+18: 3) /(12: 0+(4 \times 14: 0)+16: 0)$; based on Khas-Erdene et al. (2010). 
Table 4. Average relative area (\%) occupied by epithelium, stroma, or luminal space, tissue area measurements, number of alveoli and mean number of epithelial cell per alveolar cross-section in mammary tissue (LS Means) in Holstein cows fed diets supplemented with palm oil (PO, $\mathrm{n}=5)$ or fish oil $(\mathrm{FO}, \mathrm{n}=5)$ from day -42 to day 63 of lactation. The tissue samples were taken on 7 and $63 \mathrm{~d}$ in milk

\begin{tabular}{|c|c|c|c|c|c|c|c|c|}
\hline & \multicolumn{2}{|c|}{ Treatments $^{1}$} & \multicolumn{2}{|c|}{ Times } & \multirow{2}{*}{ SEM } & \multicolumn{3}{|c|}{ P-value } \\
\hline & $\mathrm{PO}$ & $\mathrm{FO}$ & day 7 & day 63 & & treatment & time & treatment $\times$ time \\
\hline \multicolumn{9}{|l|}{ Tissue Area (\%) } \\
\hline epithelial & 28.7 & 37.2 & 35.1 & 30.8 & 2.3 & 0.01 & 0.01 & 0.81 \\
\hline lumen & 34.4 & 32.2 & 28.4 & 38.2 & 3.7 & 0.59 & $<0.01$ & 0.03 \\
\hline stroma & 36.9 & 30.5 & 36.5 & 31.0 & 1.9 & 0.01 & 0.03 & 0.01 \\
\hline \multicolumn{9}{|l|}{ Tissue Area $\left(\mu \mathrm{m}^{2}\right)$} \\
\hline alveoli area & 4260 & 4239 & 3683 & 4815 & 206 & 0.92 & $<0.01$ & 0.03 \\
\hline epithelial area & 2256 & 2403 & 2021 & 2638 & 128 & 0.29 & $<0.01$ & 0.45 \\
\hline lumen area & 2001 & 1831 & 1645 & 2187 & 110 & 0.17 & $<0.01$ & $<0.01$ \\
\hline Epithelial cell count ${ }^{2}$ & 43.7 & 43.1 & 36.8 & 50.0 & 1.43 & 0.70 & $<0.01$ & 0.03 \\
\hline Alveoli number & 11.9 & 13.4 & 12.4 & 12.9 & 0.42 & 0.01 & 0.34 & 0.10 \\
\hline
\end{tabular}

${ }^{1}$ PO: Palm oil group; FO: Fish oil group.

${ }^{2}$ Mean number of epithelial cells per alveolar cross-section.

Table 5 provides a detailed summary of 5 size classes of alveoli and lumens. On day 7, FO had more alveoli in classes 2,3 and 5 compared to $\mathrm{PO}(\mathrm{P} \leq 0.03)$. On day 63 , the number of alveoli in classes 2 and 3 was also greater $(\mathrm{P} \leq 0.03)$ in $\mathrm{FO}$ group. But, the number of alveoli in classes 1, 4 and 5 was significantly greater in PO compared to FO. The number and distribution of classes of lumen spaces mimicked the alveoli classes. Histological changes in mammary tissue at either biopsy time or treatment group are shown in Figure 3.

\section{Discussion}

Many studies have focused on the inhibitory effects of $n-3$ PUFAs on mammary tumorigenesis (Field and Schley, 2004; McLennan and Ma, 2010), and postulated mechanisms by which $n$-3 PUFA might prevent cancer (Larsson et al., 2004) and inflammation (Calder, 2009 a). Proposed mechanisms include PUFA altering the function of intracellular signaling proteins involved in cell proliferation (Bartsch et al., 1999; Cowing and Saker, 2001). However, as an example of the complex interactions involved, the effects of dietary $n-6$ or $n-3$ PUFAs on prostanoid synthesis depends on the number of particular fatty acids reaching the target tissues (Caldari-Torres et al., 2006). Furthermore, the effect of EPA and DHA from fish oil and their intermediate functional metabolites likely determine differences in healthy and pathological conditions. To our knowledge, a study of direct effects of $n-3$ PUFAs on the growth, development, and functionality of the mammary gland in dairy cows has not been reported. 


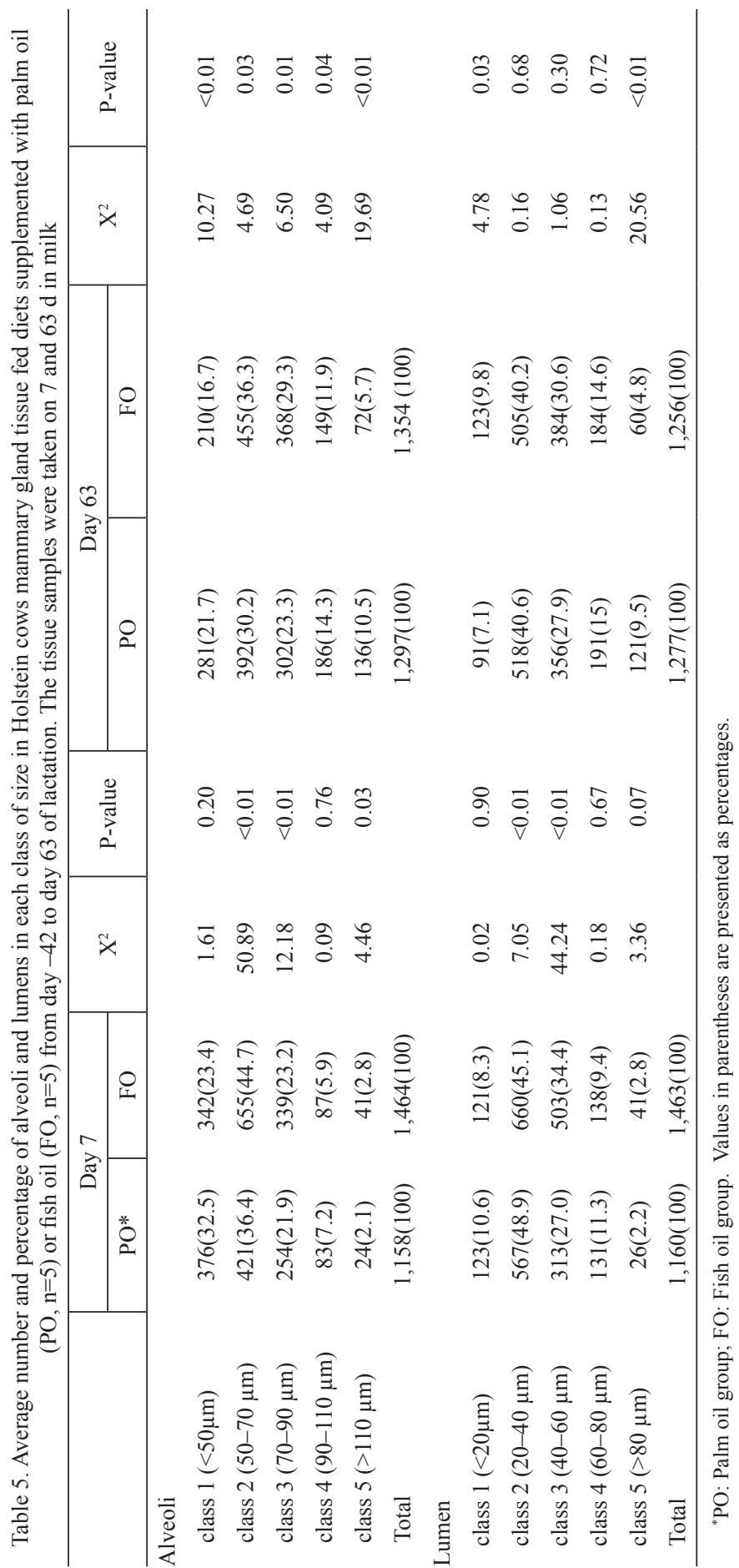



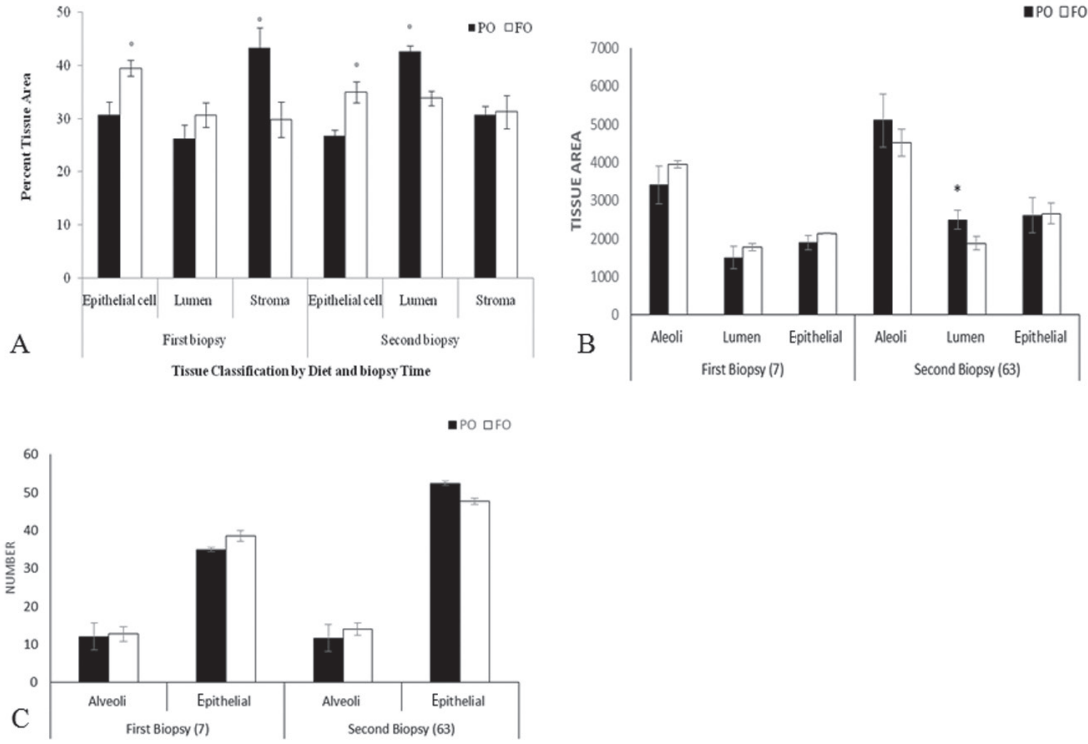

"Indicates a significant fat supplement effect $(\mathrm{P}<0.05)$ within tissue classification.

Figure 2. (A) Percentage of mammary tissue area occupied by overall epithelial cells, luminal space, or stroma per slide; (B) Alveoli, lumen and epithelial cell area $\left(\mu \mathrm{m}^{2}\right)$; (C) Number of alveoli in each slide and epithelial cell count per alveolus in Holstein cows mammary gland tissue fed diets supplemented with palm oil ( $\mathrm{PO}, \mathrm{n}=5)$ or fish oil $(\mathrm{FO}, \mathrm{n}=5)$ on day 7 and 63 postpartum. All values in the figures are given

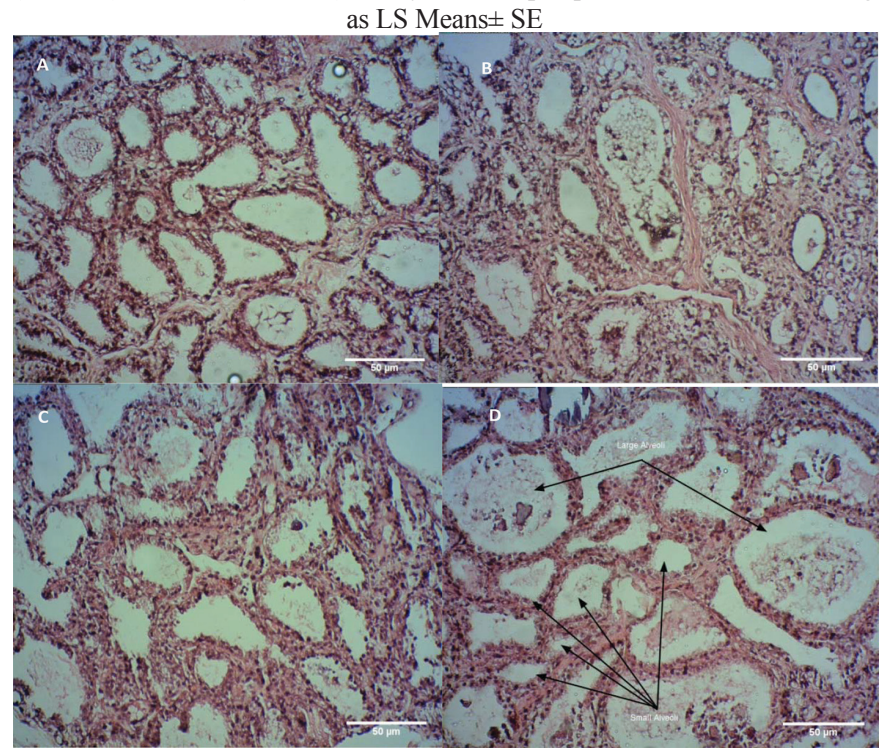

Figure 3. Mammary tissue sections for Holstein cows fed diets supplemented with fish oil at day 7 post parturition (A) and at day 63 post parturition (C) or palm oil (PO) at day 7 post parturition (B) and at day 63 post parturition (D). The arrows show large and small alveoli 
Results of dietary treatments on milk production presented here are similar to results of Whitlock et al. (2006) and Heravi Mousavi et al. (2007) who reported that milk production was higher in cows fed fish oil compared to fish meal or control diet. Other studies (Abu-Ghazaleh et al., 2002; Bharathan et al., 2008; Badiei et al., 2014) showed that supplemental fish oil had no effect on milk production or decreased it. Many factors can affect the production of milk in response to adding fat supplements. They include: forage to concentrate ratio, stage of lactation and diet composition (Heravi Mousavi et al., 2007). In our study, there was a significant reduction in milk fat yield and percentage. This agrees with the results of Dirandeh et al. (2016), who reported lower milk fat proportion for cows fed whole flaxseed during the postpartum period. Similar decreases in milk fat percentage have been observed for the cows fed flaxseed (Dirandeh et al., 2013 b), and 14.8\% extruded flaxseed (Chilliard et al., 2009) in the postpartum diet. Milk fat contributes to more than $50 \%$ of the energy in milk (Tyrrell and Reid, 1965). Therefore, it is expected that the energy saved, due to milk fat depression in $n-3$ fed cows, should be available for milk and milk component synthesis. Long-chain $n$-3 PUFA present in linseed appear to affect rumen bacteria that catalyze the terminal step in rumen biohydrogenation and cause a trans-10 FA to be produced (Griinari et al., 1998). It seems two conditions are necessary for milk fat depression: presence of a dietary unsaturated fatty acid as a substrate in the rumen and incomplete biohydrogenation as a result of rumen environment alteration, which produces various substrates and conjugated linoleic acid isomers in the rumen (Bauman and Griinari, 2001) and in milk (Weiss et al., 2013). Milk protein, lactose and total solid percentages and contents were similar between two diets consistent with other reports (Bauman et al., 2006; Jenkins and McGuire, 2006; Dirandeh et al., 2013 a, b).

Addition of fish oil changed the fatty acid composition of milk as indicated by reductions in the proportions of short (C8:0 to $\mathrm{C} 13: 0)$ and medium (C14:0 to C17:0) chain fatty acids $(\mathrm{P}<0.05)$. Similar differences were reported previously (Abu-Ghazaleh et al., 2002; Whitlock et al., 2002, 2006). Grummer and Carroll (1991) reported that when cows were fed diets that increase the supply of long chain fatty acids, an apparent reduction occurred in the de novo synthesis of fatty acids $(\leq 16: 0)$ in the mammary gland. In the present study, a number of fatty acids less than C20:0 were significantly decreased. As reported in prior studies (Abu-Ghazaleh et al., 2002; Bharathan et al., 2008; Whitlock et al., 2006), an inclusion of unsaturated oil in diet resulted in marked changes in the concentration of saturated and unsaturated fatty acids of milk fat. In our study, the total concentration of saturated fatty acids decreased and the total concentration of polyunsaturated fatty acids increased when cows were fed the FO diet, this increase was particularly evident for C20:5 (EPA) and C22:6 (DHA). Also, $n-6$ to $n-3$ fatty acid ratio decreased when FO diet was fed. Consumption of fish oil can change milk fat composition of fatty acids, which is beneficial for human health since saturated fatty acids decrease and polyunsaturated fatty acids increase in milk fat. This was reflected in an improved health index. Therefore, the results suggested that the addition of fish oil brings useful $n-3$ fatty acids into the mammary gland tissue.

Milk production depends on metabolism to support lactation as well as the number and functionality of the alveoli in the mammary gland (Akers et al., 2006). In the 
present study, mammary tissue in both experimental groups had a mature and normal appearance. We sought to determine if our treatments impacted the development of the mammary gland and thus the functional activity of the mammary tissue by quantitatively evaluating the histological appearance of mammary tissues samples collected by biopsy on day 7 and 63 of lactation. It is important to note that histological evaluations alone cannot accurately measure the impacts of treatments that might affect the total number of cells in the entire mammary gland (Smith et al., 1989). Nonetheless, such measurements can provide an index of the organization of the mammary tissue and possible impacts of treatments on the tissue and cellular characteristics of the mammary tissue. These characteristics may then provide a proxy that may reflect functional attributes of the mammary gland. For example, Akers et al. (2006) showed differences in the relative proportions of well differentiated alveolar epithelial cells that were identifiable in semi-thin sections of plastic embedded tissue, corresponding to high milk production in Holsteins compared with identically treated Hereford cows. Differences in the relative proportions of luminal space versus stromal have been shown to correspond with differences in milk production i.e. more luminal space at the expense of stromal tissue correlates with increased milk production (Akers and Nickerson, 1983; Nickerson and Akers, 1983).

The relative area occupied by mammary overall epithelium, stroma and lumen were affected by treatment and biopsy time. The percentage of tissue area occupied by the overall epithelial cell in FO was significantly increased and the percentage of stroma significantly decreased. This suggests fish oil and its functional metabolites might impact mammary tissue development in the period before and after parturition. Alternatively, omega-3 fatty acids may induce differences in metabolism that promoted changes in function that in turn alter tissue morphology. In the current study, the proportion of mammary tissue occupied by luminal space (28 vs. $38 \%$ ) and alveolar area (3683 vs. $4815 \mu \mathrm{m}^{2}$ ) increased on day 63 compared to day 7 (Table 4). It suggested that morphological changes of mammary tissue can indeed alter in correspondence with changes in milk production. Inconsistent with this data, it has been shown that increased milk production may stimulate an increase in alveolar size to accommodate greater capacity to store secreted milk prior to milking (Akers et al., 2006).

In addition, increase in the number of epithelial cells per alveolar profile (36.8 vs. 50.0; Table 4) supports the notion that there are increases in the number of alveolar epithelial cells in early lactation (Knight and Peaker, 1984) along with increasing secretory activities (Capuco et al., 2001) before the peak of lactation.

Feeding fish oil increased class 2 and 3 of alveoli in the FO vs. PO at both day 7 and 63 and consequently resulted in more uniformity in alveolar size (Figure 3 ). It provides evidence that omega-3 fatty acids altered mammary morphology (Table 5). More class 2 and 3 alveoli in the FO probably increase the ratio of surface to volume in the alveoli and could be one of the possible reasons for higher milk production in this group. Histologically, in the mammary gland of cattle and ewe, the presence of specific and large alveoli containing cells with numerous vacuoles containing fat and secreting vesicles have been identified. Lumens of these alveoli contain large amounts of vesicles. This characteristic is often found in mammary glands 10 days 
after involution, so suggesting that these specific alveoli have no longer the activity for milk production (Boutinaud et al., 2004).

\section{Conclusion}

Our data suggest that feeding a diet containing $n$ - 3 fatty acids like fish oil, compared to a diet containing saturated fatty acids as palm oil, during the dry period and early lactation, increased milk production, while decreased milk fat yield and percent and also somatic cell count. Percentage of saturated fatty acids and $n-6$ fatty acids in milk fat decreased and percentage of long chain fatty acids, unsaturated fatty acids and $n-3$ fatty acids increased, especially for docosahexaenoic acid (DHA). The $n-6$ to $n-3$ ratio in milk fat decreased and the health index of milk increased, which can be indicative of improving the health of the milk for the human consumers. In mammary gland tissue, fish oil enhanced the proportion of epithelial cell to stroma, which reflected in the increase of milk production in this group. Omega-3 fatty acids may also cause more uniformity in alveolar size and subsequently improve lactation performance in dairy cattle.

\section{Acknowledgments}

University of Tehran financially supported this research under the grant number $7108017 / 6 / 18$.

\section{References}

A b r a m off M.D., M a g e 1 h a e s P.J., R a m S.J. (2004). Image Processing with ImageJ. Bioph. Inter., 11:36-42.

Abu-Ghazaleh A.A., Schingoethe D.J., Hippen A.R., Kalscheur K.F., Whitlock L.A. (2002). Fatty acid profiles of milk and rumen digesta from cows fed fish oil, extruded soybeans or their blend. J. Dairy Sci., 85: 2266-2276.

A kers R.M. (2002). Lactation and the mammary gland. Iowa, USA, Wiley-Blackwell, 1st ed., $278 \mathrm{pp}$.

A ker s R.M., N i c kers on S.C. (1983). Effect of prepartum blockade of microtubule formation on milk production and biochemical differentiation on the mammary epithelium in Holstein heifers. Int. J. Biochem., 15: 771-775.

A k e r s R.M., C a p u c o A.V., K e y s J.E. (2006). Mammary histology and alveolar cell differentiation during late gestation and early lactation in mammary tissue of beef and dairy heifers. Livest. Sci., 105: 44-49.

AOAC International (2000). Official Methods of Analysis, 17th ed., Association of Official Analytical Chemists, Arlington, VA, USA.

Badiei A., Aliverdilou A., Amanlou H., Beheshti M., Dirandeh E., Masoumi R., Moosakhani F., Petit H.V. (2014). Postpartum responses of dairy cows supplemented with $n-3$ fatty acids for different durations during the peripartal period. J. Dairy Sci., 97: 6391-6399.

B a r t s c h H., N a i r J., O w e n R.W. (1999). Dietary polyunsaturated fatty acids and cancer of breast and colorectum: emerging evidence for their role as risk modifiers. Carcinogenesis, 20: 2209-2218.

B a u m a n D.E., Gri i n a r i J.M. (2001). Regulation and nutritional manipulation of milk fat: low-fat milk syndrome. Livest. Prod. Sci., 70: 15-29.

B a u m a n D.E., M a th e r I.H., Wa 11 R.J., L o c k A.L. (2006). Major advances associated with the biosynthesis of milk. J. Dairy Sci., 89: 1235-1243. 
Bharathan M., Schingoethe D.J., Hippen A.R., Kalscheur K.F., Gibson M.L., K a rge s K. (2008). Conjugated linoleic acid increases in milk from cows fed condensed corn distillers solubles and fish oil. J. Dairy Sci., 91: 2796-2807.

B o u t in a u d M., Gu in a r d - F l a m e n t J., J a m m e s H. (2004). The number and activity of mammary epithelial cells, determining factors for milk production. Reprod. Nutr. Dev., 44: 499-508.

B rown E.G., VandeHaar M.J., Daniels K.M., Liesman J.S., Chap in L.T., Forrest J.W., A k e r s A.M., P e ars on R.E., W e b e r N i els on M.S. (2005). Effect of increasing energy and protein intake on mammary development in heifer calves. J. Dairy Sci., 88: 595-603.

Caldari-Torres C., Rodriguez-Sallaberry C., Greene E.S., Badinga L. (2006). Differential effects of $n-3$ and $n-6$ fatty acids on prostaglandin $\mathrm{F}_{2 \alpha}$ production by bovine endometrial cells. J. Dairy Sci., 89: 971-977.

C a ld e r P.C. (2009 a). Polyunsaturated fatty acids and inflammatory processes: new twists in an old tale. Biochimie, 91: 791-795.

C a ld e r P.C. (2009 b). Fatty acids and immune function: Relevance to inflammatory bowel diseases. Int. Rev. Immun., 28: 506-534.

C a p u c o A.V., Wo o d D.L., B a ld w in R., M c l e o d K., P a a p e M.J. (2001). Mammary cell number, proliferation, and apoptosis during a bovine lactation: relation to milk production and effect of bST. J. Dairy Sci., 84: 2177-2187.

C h a $1 \mathrm{k}$ e y H.W. (1943). Method for the quantitative morphologic analysis of tissues. J. Nation. Cancer Inst., 4: 47-53.

Chilliard Y., Martin C., Rouel J., Doreau M. (2009). Milk fatty acids in dairy cows fed whole crude linseed, extruded linseed, or linseed oil, and their relationship with methane output. J. Dairy Sci., 92: 5199-5211.

C o p p o c k C.E., Wilk s D.L. (1991). Supplemental fat in high-energy ration for lactating cows: effects on intake, digestion, milk yield, and composition. J. Anim. Sci., 69: 3826-3837.

C o w in g B.E., S a k e r K.E. (2001). Polyunsaturated fatty acids and epidermal growth factor receptor/ mitogen-activated protein kinase signaling in mammary cancer. J. Nutr., 131: 1125-1128.

D e Vries L.D., D o ver H., C a s e y T., Van d e H a a r M.J., P l a u t K. (2010). Characterization of mammary stromal remodelling during the dry period. J. Dairy Sci., 93: 2433-2443.

Dirandeh E., Towhidi A., Zeinoaldini S., Ganjkhanlou M., Ansari Pirsaraei Z., F o u l a d i - N a s h t a A. (2013 a). Effects of different polyunsaturated fatty acid supplementations during the postpartum periods of early lactating dairy cows on milk yield, metabolicresponses, and reproductive performances. J. Anim. Sci., 91:713-721.

Dirandeh E., Towhidi A., Ansari Pirsaraei Z., Adib Hashemi F., Ganjkhanlou M., Zeinoaldini S., Rezaei Roodbari A., Saberifar T., Petit H.V. (2013 b). Plasma concentrations of PGFM and uterine and ovarian responses in early lactation dairy cows fed omega-3and omega-6 fatty acids. Theriogenology, 80: 131-137.

Dirandeh E., Towhidi A., Pirsara e i Z.A., S aberifar T., Akhlaghi A., Rodbari A.R. (2015). The endometrial expression of prostaglandin cascade components in lactating dairy cows fed different polyunsaturated fatty acids. Theriogenology, 83: 206-212.

Dirandeh E., Towhidi A., Pirsaraei Z.A., Zeinoaldini S., Ganjkhanlou M. (2016). Effects of dietary supplementation with different polyunsaturated fatty acids on expression of genes related to somatotropic axis function in the liver, selected blood indicators, milk yield and milk fatty acids profile in dairy cows. Ann. Anim. Sci., 16: 1045-1058.

E d m on s on A.J., L e a n I.J., We a ver L.D., F a r ver T.B., W e b s t e r G.A. (1989). A body condition scoring chart for Holstein dairy cows. J. Dairy Sci., 72: 68-78.

FASS (2010). Guide for the Care and Use of Agricultural Animals in Research and Teaching. www. Adsa.org

F eng S., L o ck A.L., Garnsw orthy P.C. (2004). Technical note: a rapid lipid method for determining fatty acid composition of milk. J. Dairy Sci., 87: 3785-3788.

F ergus on J.D., Sklan D., Chalupa W.V., Kronfeld D.S. (1990). Effects of hard fats on in vitro and in vivo rumen fermentation, milk production, and reproduction in dairy cows. J. Dairy Sci., 73: 2864-2879.

Field C.J., S chley P.D. (2004). Evidence for potential mechanisms for the effect of conjugated linoleic acid on tumor metabolism and immune function: lessons from $n-3$ fatty acids. Am. J. Clin. Nutr., 79: 1190S-1198S. 
Gri inari J.M., Dw y er D.A., M c Guire M.A., B a u man D.E., P a $1 \mathrm{~m} q u$ is t D.L., Nurme 1 a K.V.V. (1998). Transoctadecenoic acids and milk fat depression in lactating dairy cows. J. Dairy Sci., 81: 1251-1261.

Gru m m e r R.R., C a r r o 11 D.J. (1991). Effects of dietary fat on metabolic disorders and reproductive performance of dairy cattle. J. Anim. Sci., 69: 3838-3852.

Heravi M o u s a vi A.R., Gi 1 b e r t R.O., Over to n T.R., B a u m a n D.E., B u t l e r W.R. (2007). Effects of feeding fish meal and $n-3$ fatty acids on milk yield and metabolic responses in early lactating dairy cows. J. Dairy Sci., 90: 136-144.

Ho ve y R.C., M cF a d den T.B., A kers R.M. (1999). Regulation of mammary gland growth and morphogenesis by the mammary fat pad: A species comparison. J. Mamm. Gland Biol. Neopl., 4: 53-68.

I c h i h a r a K., F u k u b a y a sh i Y. (2010). Preparation of fatty acid methyl esters for gas-liquid chromatography. J. Lipid Res., 51: 635-640.

Jahani-Moghadam M., Mahjoubi E., Dirandeh E. (2015). Effect of linseed feeding on blood metabolites, incidence of cystic follicles, and productive and reproductive performance in fresh Holstein dairy cows. J. Dairy Sci., 98: 1828-1835.

J enkins T.C., M c Guire M.A. (2006). Major advances in nutrition: Impact on milk composition. J. Dairy Sci., 89: 1302-1310.

Kasaghaei S., Towhidi A., Ganjkhanlou M., Kohram H., Javaheri Barfouroos hi H. (2015). Effect of dietary omega-3 fatty acids on ovarian and insulin dynamic in Holstein dairy cows (in Persian). Iranian J. Anim. Sci., 46: 39-46.

Khas-Erdene Q., Wang J.Q., Bu D.P., Wang L., Drackley J.K., Liu Q.S., Yang G., We i H.Y., Z h o u L.Y. (2010). Responses to increasing amounts of free $\alpha$-linolenic acid infused into the duodenum of lactating dairy cows. J. Dairy Sci., 93: 1677-1684.

K n i g h t C.H., P e a k e r M. (1984). Mammary development and regression during lactation in goats in relation to milk secretion. Quart. J. Experim. Physiol., 69: 331-338.

La r s s on S.C., Ku m 1 in M., Ing e $1 \mathrm{~m}$ a n - S un d b erg M., Wo 1 k A. (2004). Dietary long-chain n-3 fatty acids for the prevention of cancer: a review of potential mechanisms. Am. J. Clin. Nut., 79: 935-945.

L in Y., L i Q. (2005). The regulation of development and lactation of mammary gland by leptin. J. Am. Sci., 1: 63-67.

L i u J., M a D.W.L. (2014). The role of $n-3$ polyunsaturated fatty acids in the prevention and treatment of breast cancer. Nutrients, 6: 5184-5223.

Mach N., van Baal J., Kruijt L., Jacobs A., Smits M. (2011). Dietary unsaturated fatty acids affect the mammary gland integrity and health in lactating dairy cows. BMC Proc., 5: S35-S38.

M c L e n n a n M., M a D.W.L. (2010). Role of dietary fatty acids in mammary gland development and breast cancer. Breast Can. Res., 12: 211-220.

Nickers on S.C., A kers R.M. (1983). Effect of prepartum blockade of microtubule formation on ultrastructural differentiation of the mammary epithelium in Holstein heifers. Int. J. Biochem., 15: $777-788$.

Norgaard J.V., Nielsen M.O., Theil P.K., Sorensen M.T., Safayi S., Sejrsen K. (2008). Development of mammary glands of fat sheep submitted to restrict feeding late pregnancy. Small Rumin. Res., 76: 155-165.

NRC (2001). Nutrient Requirements of Dairy Cattle. 7th ed. National Academic Science, Washington, DC, USA.

Ord w a y R.S., I s h 1 e r V.A., Va rg a G.A. (2002). Effects of sucrose supplementation on dry matter intake, milk yield, and blood metabolites of periparturient Holstein dairy cows. J. Dairy Sci., 85: 879-888.

P i a n t on i P., L o ck A.L., A 11 en M.S. (2013). Palmitic acid increased yields of milk and milk fat and nutrient digestibility across production level of lactating cows. J. Dairy Sci., 96: 7143-7154.

S a fa y i S., The i 1 P.K., E 1 brond V.S., H o u L., En g b a e k M., N org a a d J.V., S e j r s e n K., $\mathrm{N}$ i e l s e $\mathrm{n}$ M.O. (2010). Mammary remodelling in primiparous and multiparous dairy goats during lactation. J. Dairy Sci., 93: 1478-1490.

S ejrsen K., Purup S., Vesterga ard M., Foldager J. (2000). High body weight gain and 
reduced bovine mammary growth: physiological basis and implications for milk yield potential. Domes. Anim. Endoc., 19: 93-104.

S mith J.J., C a p u c o A.V., B e a 1 W.E., A ker s R.M. (1989). Association of prolactin and insulin receptors with mammogenesis and lobulo-alveolar formation in pregnant ewes. Int. J. Biochem., 21: 73-81.

Tyrrell H.F., Reid J.T. (1965). Prediction of the energy value of cow's milk. J. Dairy Sci., 48: $1215-1223$.

Wall E.H., A u ch tu n g T.L., D a h 1 G.E., E 11 i s S.E., M c F a d d e n T.B. (2005). Exposure to short day photoperiod during the dry period enhanced mammary growth in dairy cows. J. Dairy Sci., 88 : 994-2003.

We is s W.P., Shoe maker D.E., M c B eth L.R., S t-P i erre N.R. (2013). Effects on lactating dairy cows of oscillating dietary concentrations of unsaturated and total long-chain fatty acids. J. Dairy Sci., 96: 506-514.

We $1 \mathrm{~s} \mathrm{ch} \mathrm{C.W.} \mathrm{(1992).} \mathrm{Dietary} \mathrm{fat,} \mathrm{calories,} \mathrm{and} \mathrm{mammary} \mathrm{gland} \mathrm{tumorigenesis.} \mathrm{Ad.} \mathrm{Experim.} \mathrm{Med.}$ Biol., 332: 203-222.

Whitlock L.A., S ching oethe D.J., Hippen A.R., Kals cheur K.F., B a e r R.J., R a mas w a m y N., K a s p e r s o n K.M. (2002). Fish oil and extruded soybean fed in combination increase conjugated linoleic acids in milk of dairy cows more than when fed separately. J. Dairy Sci., 85: 234-243.

Whitlock L.A., Schingoethe D.J., Abu-Ghazaleh A.A., Hippen A.R., Kalscheur K.F. (2006). Milk production and composition from cows fed small amounts of fish oil with extruded soybean. J. Dairy Sci., 89: 3972-3980.

Received: 5 VI 2017

Accepted: 30 V 2018 